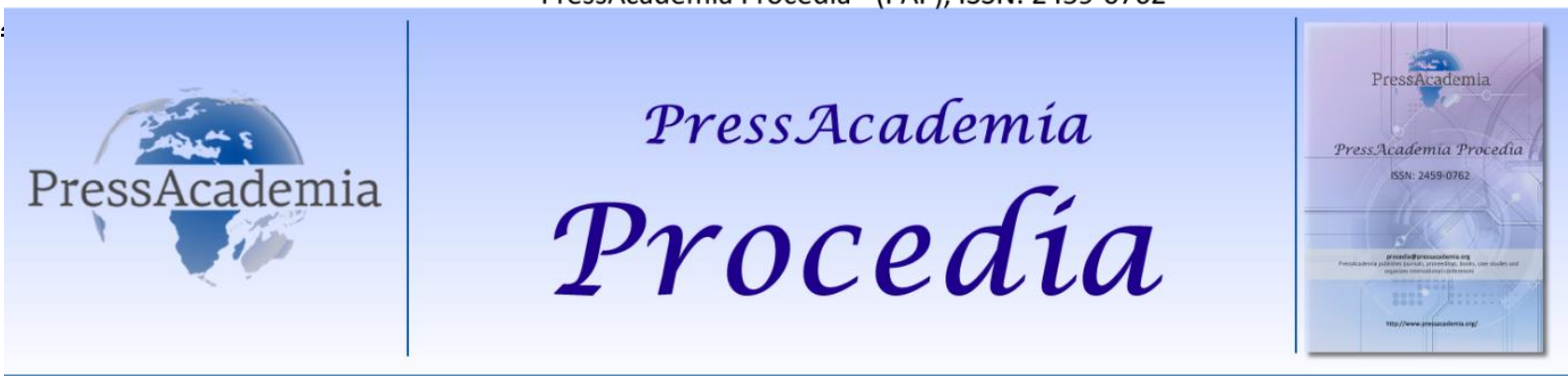

2nd World Conference on Technology, Innovation and Entrepreneurship

May 12-14, 2017, Istanbul, Turkey. Edited by Sefer Şener

\title{
STRATEGIC INNOVATION APPROACH
}

DOI: 10.17261/Pressacademia.2017.536

PAP-WCTIE-V.4-2017(28)-p.213-217

Nilhun Dogan ${ }^{1}$

${ }^{1}$ Istanbul University, dogannilhun@yahoo.com

\begin{abstract}
In recent years, the concept of innovation has become the most debated topic in literature and in particular, the strategic importance of innovation management for businesses is emphasized. In this context, the strategic innovation approach, which emerged as a synergy of innovation and strategic management, seems to play an important role in achieving sustainable competitive advantage. The aim of this article is to emphasize the importance of innovation and strategic innovation approach.
\end{abstract}

Keywords: Strategy, innovation, strategic innovation, strategic innovation approach.

JEL Codes: M10, M13

\section{INTRODUCTION}

The fact that today's economic developments and competition are so intense that it has led to a growing interest for the concept of innovation. Innovation, on the one hand, has become a driving force for economic development, while on the other hand it has become a competitive means of having strategic significance in achieving a sustainable competitive advantage for the success of the enterprises. In this context, enterprises are now turning to a strategic innovation approach that emerges as a synergy of innovation and strategic management.

In this study, strategic innovation approach was analyzed and its role and importance on success of enterprises was emphasized.

\section{INNOVATION AND STRATEGY}

Innovation has its origin in the word innovatio derived from the Latin verb innovare that means "refreshing, altering, and changing". While it was used as innovation in French, this word was started to be used with the meaning "a new product or practice that emerges as a result of a work or experiment" for the first time in English before the year 1588. Concerning the areas of use for innovation, it has such a meaning; "making a new thing in a product, device or application and making it better and more useful rather than a brand new discovery" (Akalın, 2007: 483,484). The innovation is defined in English dictionary as "the introduction of new things, ideas or ways of doing sth; a new idea, way of doing sth, etc. that has been introduced or discovered" (Hornby, 2010: 775).

The concept of strategy comes from the Greek word "strategos", and it refers to a "military general" and combines "stratos" (the army) and "ago" (to lead) (David, 2005: 24,25). The strategy first began to take its place in the business world by developing in military and political fields. The strategy is defined as identifying the roadmap, policies and tactics to be used to achieve an objective. Strategic management, on the other hand, means achieving the goal by successfully implementing this roadmap, which includes the necessary policies and processes (Çiftçi, 2011: 12, 13).

Strategic management can be defined as "the set of decisions and actions used to formulate and implement strategies that will provide a competitively superior fit between the organization and its environment so as to achieve organizational goals"(Daft, 2003: 239). The key features and elements of strategic management are illustrated in Figure 1 below: 
Figure 1: The Key Features and Elements of Strategic Management

\section{The Key Features and Elements of Strategic Management}

Strategic management is a business management process which focuses on "long-term" activities and "final results".

\section{$\downarrow$}

In the long run, it is directed to take appropriate measures by examining the threatening environmental elements "to survive".

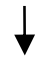

It is also directed to analyzing and ensuring the matters of business and activities that can achieve "sustainable competitive advantage" and thus "profit above average" by realizing that sustaining its existence over the long term can only be achieved with the practices and activities that will provide competitive advantage.

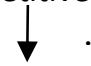

In this context, the strategic management process is an "analytical process" that involves information gathering, analyzing, being a decision-maker and implementing.

This process aims to be "effective and efficient".<smiles>[3H][3H]</smiles>

It uses "four functions of management" (planning, organizing, leading and controlling) to reach the targeted results.

Source: Prepared by utilizing from Ülgen and Mirze, 2004: 26

Supporters of modernist strategic management advocate the argument that businesses should strive to achieve competitive advantage in order to sustain their long-term survival. Competitive advantage can be only obtained through the value creating strategies. Sustainability of competitive advantage is possible only when the value-creating strategies of enterprises cannot be imitated or applied by competitors (Ülgen and Mirze, 2004: 30,31)

The most important philosophers who contributed to innovation are Gabriel Tarde, Joseph A. Schumpeter and Peter Drucker. The French sociologist Gabriel Tarde was described as the first major theorist of innovation and entrepreneurship. In addition, he was the first theoretician who defined and used the concepts of innovation and invention (Eggink, 2013: 2840).

Schumpeter, who had a great influence on the development of the economy in the 20th century, is considered one of the most influential economists of all time. He has a wide range of articles covering such topics as "the dynamics of economic and social evolution, the integration of economic, sociological and political perspectives into capitalism" and finally the "history of economic ideas" (Michaelides and Theologou, 2009: 3,5).

According to the Peter Drucker, innovation is defined as "the act that endows resources with a new capacity to create wealth". Innovation becomes a specific instrument for entrepreneurship and creates a resource (Drucker, 1993: 30).

Innovation's basic dynamic is "not everything new, but innovations that transform or be transformed into economic and social added value". Therefore, it is a fact that something that doesn't have a social and economic added value cannot be regarded as innovation. According to the social value dimension of innovation, something new is likely to be an innovation if it has the ability to meet a need of its user at a higher level than the existing ones or it can offer a much newer value that is not available. While the economic value dimension of innovation can be considered - in a narrow sense - as an economic return to the side that realizes innovation, it is considered that national and regional economies in which innovation has emerged gain a series of competitive benefits by exploiting the externality of this innovation, in broad terms. In short, innovation makes the cooperation of parties with each other inevitable (government, individuals, businesses and society) by the values and externalities that can be created together with both the commercialization and the emergence process (Uzkurt, 2010: 37). 
Innovation implies that production inputs can be transformed into sellable outputs to produce goods and services that are at a better quality - more attractive to the consumers - and less costly - easier for consumers to obtain - than the qualities / costs of goods and services that can be obtained from the current factor prices. In this regard, the innovative enterprise also refers to the business organization that performs this transformation process within the network formed that is both within the firm as a separate strategic audit unit and by the allied companies (Lazonick, 2007: 47,48). Therefore, the importance of innovation is further heightened so that businesses can be more innovative and provide competitive advantage.

Innovation has become an indispensable source of dynamism for both today's national economies and businesses. However, in order for businesses to succeed in innovation and to maximize the profits of new products and services to be offered to the marketplace, things-to-do can be briefly summarized as follows (Uzkurt, 2010: 38-50):

-An innovation strategy must be established for a successful innovation.

-A successful innovation needs a supportive cultural infrastructure and business structure.

-An effective communication network should be established with relevant resources for the production of innovation ideas and their provision from the outside.

-The right decisions should be made about what kind of innovations should be done.

-There is a need for an outward-oriented network system based on sharing and interacting internally for a successful innovation.

-The approaches that support innovation should be adopted within the enterprise.

\section{STRATEGIC INNOVATION APPROACH}

Such concepts as globalization, competition, changing customer demands, uncertainty, changing technology, environmental conditions and changing demographic structure of the workforce have driven businesses to be more productive and efficient in every area. Under these changing environmental conditions, businesses have had to develop more innovative products, methods and strategies in every area (Yeşil, 2013: 177). In this context, strategic innovation as a new approach emerged.

Many researchers use the concept of strategic innovation as a combination of strategy and innovation. According to Hamel, strategic innovation is "the ability to understand and change the industry dynamics". This condition should create wealth for stakeholders and create new value for customers by redesigning the service and redefining the market. Concerning the definitions made, strategic innovation can be said to have three consequences. Accordingly, strategic innovation leads to new markets; develops new business models; increases value for organization and customer (İplik, Topsakal and Doğan, 2014: 19).

According to another opinion, strategic innovation is "a holistic and systematic approach focused on generating beyondincremental, discontinuous or breakthrough innovations". Moreover, innovation becomes strategic when it makes a notably significant difference in valuing customers, partners, consumers and the enterprise as an intentional and repeatable process (Palmer and Kaplan, 2007: 4,5). The differences between the traditional approach and the strategic innovation approach are shown in Table 1.

Table 1: Traditional Strategy versus Strategic Innovation

\begin{tabular}{|c|c|c|}
\hline \multicolumn{2}{|r|}{ Traditional Approaches } & Strategic Innovation Approach \\
\hline$\bullet$ & $\begin{array}{c}\text { Adopt a present to future orientation-takes today } \\
\text { as the starting point }\end{array}$ & $\begin{array}{l}\text { Starts with the end in mind-identifies long-term } \\
\text { opportunities and then "bridges back to the present" }\end{array}$ \\
\hline$\bullet$ & $\begin{array}{c}\text { Accept established business boundaries/product } \\
\text { categories }\end{array}$ & $\begin{array}{l}\text { Seeks to create new competitive } \\
\text { space/playing fields }\end{array}$ \\
\hline$\bullet$ & Seek articulated consumer needs & Seeks unarticulated consumer needs \\
\hline$\bullet$ & Follow traditional, linear business planning models & $\begin{array}{l}\text { Marries process discipline with creation } \\
\text { inspiration }\end{array}$ \\
\hline$\bullet$ & May have a one-size-fits-all organizational model & $\begin{array}{l}\text { May experiment with entrepreneurial new venture or other } \\
\text { organizational structures }\end{array}$ \\
\hline • & $\begin{array}{l}\text { Focus on incremental } \\
\text { innovation }\end{array}$ & $\begin{array}{l}\text { Seeks breakthrough, disruptive innovation-while continuing } \\
\text { to build the core }\end{array}$ \\
\hline$\bullet$ & $\begin{array}{l}\text { Are technology-driven (seek consumer } \\
\text { satisfaction) }\end{array}$ & $\begin{array}{c}\text { Is consumer-inspired (seeks consumer } \\
\text { delight) }\end{array}$ \\
\hline
\end{tabular}




\begin{tabular}{|c|c|c|}
\hline - & Assume a rule-maker/taker (defensive/follower) \\
posture & $\begin{array}{c}\text { Assumes a rule-breaker (revolutionary) } \\
\text { posture }\end{array}$ \\
\hline - & $\begin{array}{c}\text { Seek input from obvious, traditional } \\
\text { sources }\end{array}$ & $\begin{array}{c}\text { Seeks inspiration from unconventional } \\
\text { sources }\end{array}$ \\
\hline
\end{tabular}

Source: Palmer and Kaplan, 2007: 4

One of the most important items listed in Table 1 is definitely the fact that innovation is now turning from incremental innovation to disruptive innovation with the strategic innovation approach. Accordingly, disruptive strategic innovation is clearly a more aggressive strategy in creating competitive advantage. The purpose of incremental strategic innovation is to create a competitive advantage, but does not aim to break down/ruin the existing market (Kataria, 2013: 18).

Strategic innovation approach is an approach that creates new opportunities based on achieving sustainable competitive advantage, meeting the needs of customers that may be important but not felt before, rewriting the rules of competition or entering into the new segments of the market that have not yet been discovered. Businesses need to adopt a strategic innovation approach that will give them a competitive advantage. Strategic innovation approach being a new approach has some features (Iraz, 2005: 111,112). These are listed in Table 2.

Table 2: Some Basic Characteristics of Strategic Innovation Approach

- Contributors of strategy plan should be diversified.

When strategies are started to be applied in the business, employees should also be involved in the strategic planning process in order not to encounter unexpected results. Because the thought of taking advantage of new product ideas and opportunities often emerges at lower levels of business. The first step of the strategic innovation approach is to create ideal conditions that will trigger extraordinary thinking and idea production by taking different opinions from different and multiple sources. In the second step, the top management should create a strategy plan by evaluating the new contributions full of fresh ideas.

- Market research should only be used to investigate unknowns.

In the strategic innovation approach, senior management behaves intellectually honest and reveals that they don't not know anything about "understanding emerging markets and delivering new values". As a sole basis for their decisions, they give up relying solely on the results of market research and prepare explorations to test the theoretical hypotheses that suggest potential opportunities for the market.

- Tolerance approach should be applied to faults during innovation process.

Innovation is not an error-free process and you must be prepared against possible errors. The process of strategic innovation is composed of partly trial and errors until finding the best and partly planning.

- Comparison should be made with different sectors.

The strategic innovation approach ensures raising standards as much as possible and creating new values by taking full advantage of the potential of benchmarking and taking practitioners around the world as reference outside their own sector.

- Success must be measured by top management's change of mind.

If an enterprise is concerned only with maintaining profitability, the assumptions underlying the traditional strategic planning may remain valid. However, if it is more important to have a sustainable competitive advantage, then the strategy needs to be revisited and considered. In short, success will depend on what will change on the basis of thought.

Source: Prepared by using İraz, 2005: 112-115

Through the strategic innovation to be built with the strategy and innovation together, it can be possible to gain competitive advantage and transform the strategies into action with such factors as valuing knowledge, creativity, creating new business models, providing new opportunities, being market-oriented, being open to different opinions and thoughts, future orientation, being exploratory, creating new values, having a mission and vision, cooperating and being extroversion (Satı and Işık, 2011: 555).

\section{CONCLUSION}

The fact that businesses are able to adapt to changing realities in a highly competitive environment together with the effect of globalization is very important in terms of not losing their position in the market. In this regard, innovation is an important tool both for businesses to survive and compete and to ensure social well-being. However, businesses need a more effective tool in today's intense competitive environment. At this point, the strategic innovation approach that emerged with the synergy of innovation and strategy has gained considerable importance. It is vital for the businesses seeking sustainable competitive advantage to adopt this new approach. 


\section{REFERENCES}

Akalın, Ş. H., (2007). “Innovation, İnovasyon: Yenileşim”, Türk Dili Dil ve Edebiyat Dergisi, XCIII(666), (Online) www.akalin.gen.tr/Eklenti/2,innovationinovasyonyenilesimpdf.pdf?0., 21.01.2017, 483-486.

Çiftçi, T. (2011). "Üç Adımda Stratejik Yönetim İstihbarat-i̇stikamet-İcraat”, İstanbul Sanayi Odası (ISO) Yayın, No: 2011/32, İstanbul, (Online) www.iso.org.tr/sites/1/upload/files/18_stratejik_yonetim-211.pdf., 15.02.2017, 1-95.

Daft, R. L. (2003). Management, Sixth Edition, Thomson Learning-South Western, USA.

David, F. R. (2005). Strategic Management Concepts and Cases, Tenth Edition, Pearson Education Inc., USA.

Drucker, P. F. (1993). Innovation and Entrepreneurship, Harper Business Edition, USA.

Eggink, M. E. (2013). "A Review of the Theoretical Context of the Role of Innovation in Economic Development", World Academy of Sciences, Engineering and Technology, International Journal of Social, Behavioral, Educational, Business and Industrial Engineering, 7(11), 2840-2846.

Hornby, A. S. (2010). Oxford Advanced Learner's Dictionary, 8th Edition, Oxford University Press.

İplik, F. N., Topsakal, Y. and Doğan, O. (2014). "Strategic Innovation: An Empirical Study On Hotel Firms Operating in Antalya Region", An International Journal of Akdeniz University Tourism Faculty, Advances in Hospitality and Tourism Research (AHTR), 2(1), 16-29.

İraz, R. (2005). Yaratıcılık ve Yenilik Bağlamında Girişimcilik ve KOBi’ler, Çizgi Kitabevi, Konya.

Kataria, S. (2013). Strategic Innovation: A Review and A Theoretical Framework, Thesis, Unıversity of Twente, Management of Governance Business Administration, January, (online) essay.utwente.nl/62857/1/Thesis_Strategic_Innovation_S_Kataria.pdf., 26.02.2017, 1-57.

Lazonick, W. (2007). "Yenilikçi İşletmeyi Anlamak- İktisat Kuramı ve İşletme Tarihinin Bütünleşmesine Doğru”, Dünya Iş̧letme Tarihi, Ed. Franco Amatori \& Geoffrey Jones, çev. Abdullah Ersoy, 1. Baskı, Dost Kitabevi, Ankara, 45-77.

Michaelides, P. G. and Theologou, K. (2009). "Joseph Schumpeter and Gabriel Tarde on Technological Change and Social Evolution", 13th Annual International Conference of the European Society fort he History of Economic Thought, Thessaloniki, Greece, April, 23-26, MPRA (Munich Personal RePEC Archive) Paper, No.67189, (online) https://mpra.ub.uni-muenchen.de/67189/1/MPRA_paper_67189.pdf., 21.04.2017, 2-29.

Palmer, D. and Kaplan, S. (2007). "A Framework for Strategic Innovation-Blending Strategy and Creative Exploration to Discover Future Business Opportunities", InnovationPoint LLC, (Online) http://www.fast-bridge.net/wpcontent/uploads/resources/A\%20framework\%20for\%20strategic\%20innovation.pdf., 21.24.2017, 1-22.

Satı, Z. E. and Işık, Ö. (2011). “Inovasyon ve Stratejik Yönetim Sinerjisi: Stratejik İnovasyon”, CBÜ Sosyal Bilimler Dergisi, 9(2), 538-559.

Ülgen, H. and Mirze, S. K. (2004). İşletmelerde Stratejik Yönetim, Literatür Yayıncılık, İstanbul.

Uzkurt, C. (2010). “İnovasyon Yönetimi: İnovasyon Nedir, Nasıl Yapılır ve Nasıl Pazarlanır?”, Ankara Sanayi Odası Yayın Organı, Temmuz/Ağustos (Online) www.aso.org.tr/b2b/asobilgi/sayilar/4dosyatemmuzagustos2010.pdf., 17.03.2017, 37-51.

Yeşil, S. (2013). Küreselleşme ve Değişen Çevre Dinamikleri Işığında Yeni Yönetim Yaklaşımlarından Seçme Konular, 1. Baskı, Seçkin Yayıncılık, Ankara. 